\title{
Is An Un-registered Married Woman Protected in Indonesia?
}

\author{
Rosmalinda \\ PhD in Law Program, Graduate School \\ Universitas Sumatera Utara (USU-Medan) \\ Medan, North Sumatera, Indonesia \\ rz_linda@yahoo.com, rosmalinda@usu.ac.id
}

\author{
Ningrum Natasya Sirait \\ PhD in Law Program, Graduate School \\ Universitas Sumatera Utara (USU-Medan) \\ Medan, North Sumatera, Indonesia \\ Ningrum.sirait@gmail.com
}

\begin{abstract}
Nowadays, there are some un-registered marriage cases which involved women in the world. One popular case in Indonesia is an Actress who married with a former ministary in New Order. In 2010, she claimed her marriage and child rights to the Constitutional Court. The Court decided that her child has his status as the son of the Actress and the Ministry meanwhile her status is not recognized as a wife. The main reason is her marriage was not registered. This situation is unfair, how can a woman who delivered her biological child does not recognized as a real mother in her wife status? In our point of view, state should not ignored the woman's rights either her marriage was registered or not particularly when the state legalized her child status through birth certificate. In the context of CEDAW and CRC, Indonesia should revise some regulations related with women who un-registered their marriages. It is a must in order to achieve equal justice before the law. Registration of a marriage process must be claimed as State obligation in order to fulfill its citizen's right in civil rights.
\end{abstract}

Keywords—un-registered marriage; CEDAW; CRC; justice

\section{INTRODUCTION}

Un-registered marriages are available around the world. It does not happen to specific religion, tribe, educational or economic level. Iraq, Cambodia and Indonesia are three countries which facing problem on unregistered marriage. Based on the data of the Indonesian Ministry of Religious Affairs, there are many unregistered marriages in 5 districts in Indonesia namely Bangkalan District with 1,156 cases among 2009-2012, while in period of 2010-2012, Indramayu with 1,144 cases, Malang with 756 cases, Tangerang with 300 cases and Yogyakarta, there were only six cases.[1]

Various factors are responsible for the unregistered marriage, for instant, polygamy and contract marriage. [2] The cases which occurred in Puncak-Bogor have impact not only for the women on her marital status but also her child regarding the citizenship of the biological father who is an expatriate. He stays in Indonesia temporary. [3] Other factors, the ignorance of the couple to register their marriage since they belief registration is not a compulsory as a rule of their religions. Being old and do not want people know his/her marriage are additional factors. Last but not least as the factor is underage marriage.[4]
These factors are also available in Indonesia. There are around 142 million girls married before adulthood in this decade (CFR 2015). [5] Unfortunately, Indonesia has the highest number of child marriage, globally, Indonesia is one of the ten countries with the highest rate of child marriage according to Council of Foreign Relations while in the ASEAN region, Indonesia became the second country after Cambodia. The number shows that one in five girls is not yet 18 years old. [5]

This paper will find out the protection of Indonesia as a state party of CEDAW and CRC in specific for women and girls whose unregistered marriage. The research uses those two international Conventions and analyzes the gap of Indonesian legislation and the implementation of CEDAW and $\mathrm{CRC}$ in order to conduct the state obligation.

\section{UN-REGISTERED MARRIAGE IN SOME COUNTRIES}

Iraq has un-marriage issues in their community which has various religions. Iraqis who married based on their various beliefs in temples, churches or other private places are required to register their marriage in court both in the court for the Muslims or "Personal Items Court" for non Muslims. The couple will get their official marriage documents after they do the registration. However, Couples who not registered their marriage, there are consequences such as inavailibility of official marriage documents in regard of the legitimating of their married status. As an impact, they could not access their civil rights. [6]

Cambodia, as the country with the highest number of child marriage in ASEAN, requires its citizens to register the marriage to the Council of Commune in the area of female residence. Furthermore, the couple should wait for 10 days for marriage announcement to avoid the objections of other parties including persons. This marriage registration requires the couple to pay 400 Riels which equal with IDR 1.325,95, Kurs 1 IDR $=3.3$ Riel.[7] Furthermore, couples who not registered their married will known as illegally married, the impact will appear in divorce process. The women also will not entitled to property during marriage or the right of child support because the father of the child is not recognized by law either.[7] 
As the impact of un-registered marriage, Indonesia has similar situation with Iraq and Cambodia namely nonfulfillment of rights of women and girls for example Civil Rights. A child of un-registered marriage women faces a problem to have birth certificate. Furthermore, her/his birth certificate only declared the mother's name. A research conducted in Sukabumi, Karawang, Subang and Cianjur districts show that 15 to 20 percent of birth certificate only mentions mother's name.[5] This situation will place the children in unfair position since it is must for every child to have his/her father's name stated in her/his birth certificate. In the future, this child will be bullying for his friends as "Anak Haram (Illegal child". One popular case in Indonesia involved a child of an Artist whose marriage is un-registered. She requested a legal review of Law No. 1 year 1974 concerning marriage regarding the status of the child and the relationships between his mother and father. [8]

\section{INTERNATIONAL LAWS}

The Universal Declaration of Human Rights (DUHAM) submitted in 1947 and ratified by the United Nations General Assembly on 10 December 1948 constitute the basis of the non-discriminatory principle. One important principle that ensures women and men are equal is Non Discrimination. Article 16, paragraph 1 and 2 states that Adult male and female entitled to marry and to form a family without difference based on his/her nationality, citizenship or religion. Furthermore, it is mentioned that couple have the freedom in determining and giving their consent in marriage. This principle is subsequently reiterated in the conventions that deal specifically with women and children groups, as will be explained below.[9]

\section{A. Convention on the Elimination of Anti Discrimination and Violence Against Women (CEDAW)}

CEDAW guarantee the rights of women in marriage in article 16. This article states that every woman in marriage has the same position as men and is entitled in: 1) Entering marriage 2) Choosing a husband freely and for entering marriage only with the consent which is free and full; 3) Equal rights and responsibilities as parents, regardless of their marital status in matters relating to children; 4) Equal rights and responsibilities during marriage and at termination of marriage; 5) Predict the birth of a child, enlightened, educated to exercise the right; 6) The same rights and responsibilities with respect to guardianship, care, supervision and adoption; 7) The same personal rights as husband and wife, including to choose a family name, profession and occupation and; 8) The same rights for both spouses relate to the ownership of the acquisition, management, enjoyment and transfer of property.[10]

Indonesia is a state party of CEDAW by ratifying this Convention through Law No 7 Year 1984 concerning Convention on the Elimination of All Forms Discrimination Against Women. As a consequence of this ratification, Indonesia is obliged to guarantee, protect and fulfill all citizens' rights including women's rights

\section{B. Convention on the Rights of the Child $(C R C)$}

There are 4 principles stated in CRC namely Non Discrimination, life and growth, Child participation and best interests of the child. The Non-Discrimination Principles stated in Article 2 of the CRC is very fundamental for consideration of the state party in order to respect and ensure all child rights of CRC. Furthermore, the best interest of the child principle is adopted from Article 3 paragraph 1 of the $\mathrm{CRC}$. This principle is a foundation for the executive authority such as social welfare institutions in the public sector or private, court, administrative authority, or legislative.

\section{LAW AND PRACTICE IN INDONESIA}

Every state party such as Indonesia has obligation to implement the international instruments. There are four obligations of Indonesia who ratifies CEDAW and the CRC namely to respect, fulfill, protect and promote. This paper will describe how Indonesian law provides protection for unregistered marriage women and girls.

\section{A. Law No 1 year 1974 concerning Marriage}

Discussing about un-registered marriage women, it is a must to analyze Law No 1 year 1974 concerning marriage and its implementing instrument namely Peraturan Pemerintah/ Government Act No. 9 year 1975. Nowadays, there are some debates in the interpretation of article 2 which mentioned that a legal marriage must be conducted under religion and belief rules. Furthermore, it also mentioned that each marriage must be registered under applicable laws and regulations. [11]

Some studies show that registration may not be performed by the couple due to some reasons. First, do not fulfill the requirements of Law No. 1 of 1974 in Chapter II on the precise terms of marriage of Article 6 which states that it will not be registered if no consent of the brides and one or both brides have not reached the age of 21 (twenty one) years old neither do not get permission from both parents. [5]

Unfortunately, the statement in article 6 is annulled by the existence of article 7 which allows marriage for male who is 19 y.o. while the female is 16 y.o. Furthermore, this law contributes children marriage which will be unregistered marriages unless based on article 7 paragraph 2, there is an exception from the Court or other state officers appointed by both parents of the brides.[11]

As stated above that a factor which contributed unregistered marriage is when a husband has more than 1 wife and does not get permission from his first wife. Article 3 paragraph 1 of Law No. 1 of 1974 mentions the principle of marriage is relative. It means, although it stated that every person may only have a wife/husband there is an opportunity that a man may have more than one wife when the court gives permission to a husband. Mostly, the cases in having the second wife involved men who do not fulfill the requirements of Law No1 Year 1974 as stated in article 5. It mentions that the husband must have the consent of the wife/wives. He also must be able to guarantee the necessities of life of his wives 
and their children. Moreover, it must be ensure that husband will be fair to his wives and their children.

North Sumatra Police department reported that there is a case of psychic violence and neglected of an unregistered marriage women. She reported his husband since she thought that his husband commit a crime which regulated in Law No. 23 year 2004 concerning Kekerasan dalam Rumah Tangga/the Elimination of Domestic Violence. This law defined a domestic violence in article 1, paragraph 1 and 2 which stated that Domestic violence is every act against a person, especially a woman, resulting in physical, sexual, psychological, and/or neglect of the suffering or suffering of a household including threats of committing, or unlawful deprivation of liberty within the scope of a household.

Furthermore, it stated the scope of household which consist of husband, wife and child. The un-registered marriage such as the mandate of article 2 of Law No. 1 of 1974 is questioned in this paper. It is very interesting since the unregistered marriage women has two sons who have birth certificates within the name of their parents, wife and husband, are available

\section{B. Decision of the Constitutional Court}

There are two decisions of the Constitutional Court which has function to examine the constitution in Indonesia. It decided requested from Indonesia citizens related to unregistered marriages. Firstly, Decision of the Constitutional Court Number 46/PUU-VIII / 2010 concerning the petition for judicial review of Law No. 1 of 1974 on Marriage against the 1945 Constitution. Secondly, the Constitutional Court Decision No 18/6/2015 on the petition for judicial review of Article 7 paragraph 1 of Marriage Law Number 1 Year 1974 about Minimum marriage limit for women, minimum 18 years.

The first Constitutional Court's decision concerning cancelation of the application of article 2 paragraph (2) the administrative registration of marriage. It mentioned that state is intended to make marriage, as an important legal act in the life of the person concerned, which implicates the enormous legal consequences, in the future can be proved by perfect proof with an authentic deed so that the protection and service by the State in relation to the rights arising out of a marriage can be organized in an orderly and efficient manner. That is, by having authentic proof of marriage deed, the rights arising as a result of marriage can be protected without needed to further proof. [12]

However, for the child's relationship with his father, Article 43 paragraph (1) of Law Number 1 Year 1974 on Marriage stating "Child born only having a civil relationship with his mother and his mother's family ", has no binding legal force as long as it is understood to be a civil relationship with men which can be proven on the basis of science and technology and / or other evidence according to law apparently has blood relation as his father, it must be read, "A child born outside marriage has a civil relationship with his mother and his mother's family and with a male as his father which can be proven on the basis of science and technology and / or other evidence of law having blood relations, including civil relations with his father's family ". This change brought about an important change for a child born of unregistered marriage. However, for married women not recorded, still lack of fulfillment of rights from the State of Indonesia.

The second Constitutional Court's Decision No. 18/6/2015 resulted in the limitation of marriage age which is the cause of the unregistered marriage of the bride age, 16 years. [11] This law also allows for the dispensation of girls and boys to marry early - one of the highlights related to the fulfillment of the rights of children in Indonesia submitted by the International Committee on the Rights of the Child (ICRC). This law is contrary to the Child Protection Act Number 23 year 2002 (revised in 2014) stating that the child's age is under 18 years old and the parent is responsible for preventing marriage of the child's age. [13] Further rejection of the Constitutional Court on the request of Judicial Review filed by civil society in 2015 to the Constitutional Court to raise the age limit of marriage to 18 years for girls is not granted with religious interpretation argument very disappointing public. This refusal is evidence of legal inconsistency with existing and nonaligned international and national instruments especially the best interest of children principle.

\section{FINAL REMARKS}

As a state party of CEDAW Indonesia should not only respect, promote and fulfill the right of women. In particular, the obligations of the state of Indonesia as a participating country that has ratified the United Nations should provide protection to women whose marriages are not registered, especially girls. They become victims of unrecognized marriage due to age that does not meet the requirements of marriage registration.

We also argue that un-registered marriages especially when there are minors should not place women and girls in unfair treatment since her status as a wife is recognized by the law. Although she has no legal status as a wife, as a mother she must be identified as member of a house who protected by the state of any kind of violations.

Moreover, in our opinion, Indonesia as a state party to CEDAW and CRC should not neglect the rights of women in civil or economic and social rights. The un-registered marriage experienced by adult women should be seen as a limitation of Indonesia's ability to provide the right for the citizens while for girls, it is time for Indonesia to increase the marriage age of girls to 18 years so that it is in harmony with its obligation to protect children according to the principles of CRC that are in the best interest for children.

\section{References}

[1] http://www.hukumonline.com/berita/baca/lt50df765e9b48d/banyaksebab-perkawinan-tak-dicatat; accessed on 15 September 2017

[2] http://www.kpai.go.id/tinjauan/perkawinan-tidak-dicatatkandampaknya-bagi-anak/ accessed on 30 September 2017

[3] http://www.hukumonline.com/berita/baca/lt57ddcf46be430/persoalanperlindungan-hukum-bagi-anak-hasil-kawin-kontrak, accessed on 30 September 2017 
[4] http://www.hukumonline.com/berita/baca/lt50df765e9b48d/banyaksebab-perkawinan-tak-dicatat; accessed on 15 September 2017

[5] Dewi Candraningrum, Anita Dhewy \& Andi Misbahul Pratiwi; Takut akan Zina, Pendidikan Rendah, dan Kemiskinan:Status Anak Perempuan dalam Pernikahan Anak di Sukabumi Jawa Barat (Fear of Zina, Poor Education, and Poverty:Status of Girls in Child-Marriage in Sukabumi West Java)Jurnal Perempuan, Jurnal Perempuan, Vol. 21 No. 1, Februari 2016 p. $150-154$

[6] Iraq Access to Justice Program Values of Access to Justice and Unregistered Marriage, 2014, http://pdf.usaid.gov/pdf docs/PA00K2Z4.pdf, accessed on 15 September 2017

[7] Legal and Gender Issues of Marriage and Divorce in Cambodia, Dorine Van Der Keur, Volume 3 - December 2014, Cambodian Law and Policy
Journal, p. http://cambodialpj.org/article/legal-and-gender-issues-ofmarriage-and-divorce-in-cambodia/ accessed on 30 September 2017]

[8] http://www.bphn.go.id/data/documents/putusan_46-puu-viii2010_(perkawinan).pdf

[9] http://www.ohchr.org/EN/UDHR/Documents/UDHR Translations/eng.p df , accessed on 10 September 2017

[10] http://www.ohchr.org/Documents/ProfessionalInterest/cedaw.pdf, accessed on 10 September 2017

[11] Undang-Undang No 1 tahun 1974 tentang perkawinan/Marriage Law no. $1 / 1974$

[12] MK Nomor 46/PUU-VIII/2010 atas permohonan pengujian UU No 1 Tahun 1974 tentang Perkawinan terhadap Undang-Undang Dasar 1945

[13] Child Protection Law no. 23/2002, article 26, 1 (c). 